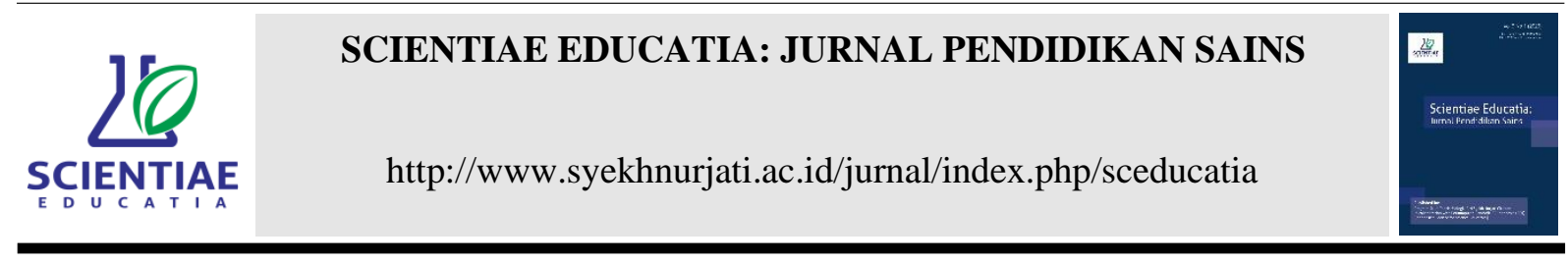

\title{
Development of Student Worksheets Based on Socio-Scientific Issues (SSI) on Climate Change Materials for Junior High School Students
}

\author{
Meli Ameliawati*, Ading Pramadi, Meti Maspupah \\ Department of Biology Education, Faculty of Education and Teacher Training, UIN Sunan Gunung Djati Bandung, \\ Indonesia
}

${ }^{*}$ Corresponding author: J1. A.H Nasution.No 105. Cibiru. Kota Bandung, Jawa Barat 40614. Indonesia. Email addresses: meliameliawati.edu@gmail.com

\begin{tabular}{|c|c|}
\hline article info & a b s t r a c t \\
\hline $\begin{array}{l}\text { Article history: } \\
\text { Received: } 04 \text { April } 2021 \\
\text { Received in revised form: } 20 \\
\text { May } 2021 \\
\text { Accepted: } 20 \text { Juni } 2021 \\
\text { Available online: } 30 \text { Juni } 2021 \\
\text { Keywords: } \\
\text { Climate change } \\
\text { Legibility response } \\
\text { Socio-scientific issues } \\
\text { Worksheet }\end{array}$ & $\begin{array}{l}\text { This research is motivated by the lack of development of Socio- } \\
\text { Scientific Issues-based worksheets, especially on materials related to } \\
\text { social and environmental issues, so the purpose of this study is to } \\
\text { analyze student responses to the development of Socio-Scientific } \\
\text { Issues-based worksheets on climate change materials. The research } \\
\text { method used is Research and Development (R\&D) research with a } \\
\text { 4-D development model modified to 3-D. The implementation only } \\
\text { reaches the product development stage due to time constraints and } \\
\text { the Covid-19 pandemic. Research data analysis is generally obtained } \\
\text { from literature studies and field studies. Field studies were obtained } \\
\text { from research conducted on } 30 \text { class VII students of SMP Negeri } 1 \\
\text { Cisalak in the even semester of the } 2020 / 2021 \text { academic year using } \\
\text { an initial needs analysis questionnaire and a student readability } \\
\text { response questionnaire the worksheet that had been made. After the } \\
\text { revision and evaluation of the draft results, the worksheet SSI is } \\
\text { ready to be used for research. From the results of the student } \\
\text { readability questionnaire on the SSI worksheet, the average result of } \\
\text { the readability assessment was } 90 \% \text {. The results obtained that the } \\
\text { SSI worksheet developed in the very valid category and suitable for } \\
\text { science learning class VII, especially on climate change material. } \\
\text { Researchers recommend that Socio-Scientific Issues (SSI)-based } \\
\text { worksheets can be an alternative learning, especially on science and } \\
\text { environmental problems materials. }\end{array}$ \\
\hline
\end{tabular}

2021 Scientiae Educatia: Jurnal Pendidikan Sains

\section{Introduction}

Education is essentially an effort in order to educate a human civilization by building the strength of the soul and body of students both outwardly and inwardly. As long as humans live, they will continue to receive education, because education is a continuous system and will only end when humans are no longer in the world (Sujana, 2019). In this education there is a learning and learning process. According to (Pane \& Darwis Dasopang, 2017) learning is defined as an effort for the transformation of character and personality changes from the processes that are intertwined by students with their natural surroundings. While learning is interpreted as a system that composes, regulates interaction and communication between students and their environment so that they can support student achievement and learning. In addition to the environment, students also interact and communicate with teachers who are educators. 
The learning process from time to time is always changing and following the changing times. Education is currently entering the 21st century. According Komara (2018) entering the 21st century the learning process now requires students to be independent in finding sources and information that can support learning, not just fixating on information that is only obtained from the teacher. In addition, according to Astuti \& Setiawan (2013) the main center of science learning in the 21st century is the aspect of knowledge, skills and student behavior. Of course, in an effort to achieve these aspects requires a curriculum that is in accordance with the developing times.

Planning of teaching tools is very important for active student involvement in learning (Fikria \& Prodjosantoso, 2021).According to Chotijah and Suparman in Maryamah, Anriani, \& Fathurrohman (2019) the alertness and stability of the teacher in preparing learning is very much needed in this 21 st century science learning. In this preparation, indicators that can support include alternative teaching materials and the application of skills needed in the 21st century. Therefore, a teacher should ideally have the ability and creativity in developing a teaching material. This is also in line with what was conveyed by Anggraini, Wahyuni, \& Lesmono (2016) that teaching materials are one of the supporters who can help the learning process run smoothly. According to Chomsin (2008) teaching materials are a set of rules and procedures in carrying out a lesson which includes a summary and evaluation of learning.

Today's learning is carried out online or what we call online. The main problem in online learning due to Covid-19 is that teachers are limited in delivering material so that a summary of the material is needed so that students can understand and study the material in their respective homes. The summary in question can be applied to a simplified teaching material into a student worksheet. According to (Muslimah, Rosalina \& Febriandi (2021) student worksheets is a collection of exercises regarding the material that will be studied by students as an effort to develop abilities and skills to achieve the expected learning objectives.

The basic competencies that are expected and should be included in a teaching material are that students are able to be directly involved in solving issues/problems related to the environment and are proficient and follow the development of developing technology (Putriana, 2020). Based on the results of interviews and questionnaires at SMP Negeri 1 Cisalak, it is known that at the school there is no student worksheets development that includes these aspects. Student worksheets which are commonly used still only use concepts and theories, not yet able to reflect the relationship between science and everyday life. Student Worksheets, which are commonly used, still only use concepts and theories, not yet able to reflect the relationship between science and everyday life. In addition, based on the results of interviews with students, it was said that the contents of the Student Worksheets used were not colored and used opaque paper. In addition, from the problems that have been described, an approach that can be a solution to learning that is expected to be included in the 21st century learning process is Socio-Scientific Issues (SSI).

Socio-Scientific Issues (SSI) is a science learning approach that incorporates social and environmental issues that are currently being discussed in the community. Then in its completion requires cognitive and moral abilities as well as ethics. So that in the application of the SocioScientific Issues (SSI) approach, it is very necessary to have the ability to think and discuss students (Rachmawati \& Diningsih, 2021). The content that is usually discussed in SocioScientific Issues (SSI) always focuses on the environment. In Socio-Scientific Issues (SSI) problems are presented and associated with social and environmental problems and issues which in their completion require science and morals (Sadler, 2004). In addition, cognitive, effective and psychomotor knowledge as well as a sense of caring for the environment are also stimulated from learning with this socio-scientific issues approach (Fibonacci, 2020). Direct understanding and 
application provides an initial framework for conceptualizing the type of Discourse expected in the community of practice involved in negotiating Socio Scientific Issues (Sadler, 2009). The ability to make informed decisions about science-related social issues is considered an important attribute of scientific literacy (Lee, 2007).

In a previous study conducted by Rahayu et al (2017) stated that Socio Scientific Issues-based learning is associated with social issues that arise in society such as the environment. Environmental emergency problems become a problem because of human domination over the environment, one of which is the exploitation of environmental resources, and the development of technologies that are not environmentally friendly. Thus education plays an important role in educating students to care about the environment. According to the findings obtained from research conducted by Anagün \& Özden (2010), social-scientific problems serve as providing a general culture, understanding the relationship between science-technology-society-environment, developing scientific process skills, thinking, discussing, problem-solving skills, acquiring attitudes and morals. In addition, participants stated that socio-scientific issues enrich the learning environment and increase interest in science and technology.

Based on Yaumi et al (2019) related to the development of Sosio-Scientific Issues oriented science material on climate change material, it is said to be "valid, practical and effective". From the research that has been done, it is known that the students received a "positive" response with a percentage of $94.10 \%$ which indicates the "very good" criteria. Student responses have not shown $100 \%$ because learning has not been followed by students optimally and consistently in applying Socio-Scientific Issues in learning. Based on the results of research from Foong \& Daniel (2010) the emergence of scientific issues that exist in the community forces students to be able to argue from the information they hear and get. Currently the issue that is being hotly discussed in the community, one of which is the problem of climate change which in its completion requires political and moral aspects (Espeja \& Lagarón, 2015). Not only students, the Socio-Scientific Issues approach is also important to be mastered by teachers because it has benefits and provides its own challenges for teachers when teaching in class (Friedrichsen et al., 2016).

One of the materials contained in the even semester VII science class and is a global problem that is always experienced by all countries in the world is climate change and global warming. This is in line with what Nazilah (2019) conveyed, the content that can be used as discussion material is about climate change and global warming. According to (Campbell-Lendrum, Woodruff, Prüss-Üstün, Corvalán, \& Organization (2007) threats to human health around the world, one of which is influenced by climate change. In Socio-Scientific Issues (SSI) students are honed to be able to make decisions on the problems at hand because they are trained to be able to think critically and rationally (Sadler et al., 2016). By studying Socio-Scentific Issues, it is hoped that it can help a little with these health problems because students become more concerned and sensitive to nature and their environment (Aisya, Wibowo, \& Aminatun, 2017). Common examples of SSI include climate change, genetic technologies, medical controversies like vaccination, and questions related to energy sources and consumption patterns (Friedrichsen et al., 2016)

Research conducted by Rahayu et al (2017) develops SSI-based LKS and lesson plans that are suitable for use in grade VII SMP. Then the research conducted by Yaumi, Madlazim, \& Taufikurohmah (2019) regarding the development of SSI-based science material on climate change material which is considered "valid, practical and effective". Student response to learning is also very good. Based on the explanation that has been described, the research conducted is entitled "Students' Readability Responses to the Development of Worksheets on Social-Scientific Issues on Climate Change Materials". Based on the results of research from Hariapsari et al 
(2018) which stated that the teaching materials based on socio-scientific issues on the vibration, wave, and sound material he did, the results of the LKS validity were declared to be very valid. This is supported by an average score of more than 3.50. The novelty or research findings of this paper are the validity of teaching materials based on the socioscientific issues approach on the topics of vibration, waves, and sound; This research can be implemented in the scientific learning process and can improve students' scientific literacy.

Then the question that can be asked is how students respond to the Socio-Scientific Issues (SSI)-Based Worksheet on climate change material. The purpose of this research is to describe and analyze the response of students' readability to a media of teaching materials in the form of Socio-Scientific Issues (SSI)-based worksheets on climate change materials.

\section{Method}

This research uses Research and Development (R\&D) research with a 4-D development model. However in its implementation, modifications are made to 3-D which consists of Define, Design, and Develop (Lawhon, 1976). From the results of this study, teaching materials in the form of worksheets based on Socio-Scientific Issues on climate change material were produced.

The data obtained in the field were obtained from 30 class VII students of SMP Negeri 1 Cisalak in the even semester of the 2020/2021 academic year. Data collection was carried out by providing a student readability response questionnaire consisting of various questions that students had to answer.

The research instrument is about the analysis of initial needs and a questionnaire of students' reading responses to the student worksheets. The student readability response instrument includes questions regarding student assessments of the SSI worksheets that have been made. Aspects that are seen are in terms of appearance, presentation of material and benefits of student worksheets. The assessment of the percentage of students' readability responses can be seen as follows (Sriwiyana, 2011).

Table 1. Percentage of student readability results

\begin{tabular}{cc}
\hline Percentage & Category \\
\hline $0-20 \%$ & Very Inappropriate / Very Invalid \\
$21-40 \%$ & Less Eligible/Invalid \\
$41-60 \%$ & Sufficiently Eligible/Sufficiently \\
$61-80 \%$ & Eligible/Valid \\
$81-100 \%$ & Very Eligible/Very Valid \\
\hline
\end{tabular}

\section{Result and Discussion}

The development of Student Worksheets based on Socio-Scietific Issues (SSI) begins with the define stage. At the define stage, an analysis of the needs of students is carried out. Based on the results of observations, it is known that one of the difficulties of students during online learning is understanding the material due to the lack of teaching materials and only limited from the sources provided by the teacher. Conventional student worksheets books sourced from the government which are commonly used by teachers during learning are also considered too contextual and only contain exercises and questions.

From the observations made, it is also known that students are still fixated on concepts and have not been able to connect their knowledge with nature and the environment. From the observations, it is also known that students still have difficulty understanding climate change material, apart from too many terms that are not understood, it is also added that the existing teaching materials have not explored and linked climate change problems with students' daily lives. 
The next stage is design (design). Departing from the existing problems, then a research instrument was made. The research instrument made focuses on the material of climate change and global warming. At this stage, the selection of media that fits the material to be studied is also carried out. After conducting the analysis, student worksheets was determined as the right medium and the Socio-Scientific Issues (SSI) approach as an approach that could be applied to climate change material. At this design stage, an initial draft of the student worksheets is produced.

The initial draft of the student worksheets that had been prepared was then validated by expert lecturers. Expert lecturers who validate are material experts and media experts. Material expert lecturers who validate are lecturers who concentrate on the environmental field and are experts in their fields. Meanwhile, media validation is carried out by lecturers who are experts in the field of media development. At this validation stage, the media was also revised according to the suggestions and comments from the validator.

After the student worksheets media has been validated and revised, the next step is to conduct research. This research aims to see the response of students' readability to the developed media. The participants' readability response test is a benchmark in the development of Student Worksheet based on Socio-Scientific Issues (SSI). The research developed was carried out only up to the limited test stage. The limited test was carried out by making a student readability response questionnaire taken from the instrument that had been made. The student worksheets instruments are grouped into three aspects, namely aspects of appearance, presentation of material and benefits.

In its implementation, a limited field test was carried out to 30 students of class VII SMP Negeri 1 Cisalak. This readability test is carried out online via Google Meet. The stage is that it begins with providing an explanation in advance to students regarding the intent and purpose of the limited test to be carried out. After that, the student worksheets is given to students with the aim of being studied, read and understood first. Furthermore, a readability response questionnaire was given to students to be filled in according to the responses and assessments of each student on the student worksheets.

With the responses from these students, it becomes a benchmark and improvement in the future if there are still some things that must be improved from the student worksheets. From the results of the student's responses, in general, the student worksheets is good and feasible to use. From the results of the response questionnaire, some students hoped that this student worksheets could be printed to make it easier to use.

Processing the data obtained from the results of the readability response test from 30 student samples, it was stated that the Student Worksheet based on Socio-Scientific Issues (SSI) on climate change material was very good and very feasible to be used in the learning process with the acquisition of scores as shown in Table 2 below (Ameliawati, 2021).

Table 2 . Results of student readability response test analysis

\begin{tabular}{cccl}
\hline No & Aspect & Percentage & Information \\
\hline 1 & Appearance & $87,32 \%$ & Very Worthy \\
2 & Material Presentation & $90,28 \%$ & Very Worthy \\
3 & Benefit & $92,66 \%$ & Very Worthy \\
& Percentage Average Readability & $90 \%$ & Very Worthy \\
\hline
\end{tabular}

From the average percentage of readability of media students, it is stated that it is very good and very feasible with an average percentage of readability of $90 \%$. The following is a cover display and the Student Worksheet based on Socio-Scientific Issues (SSI) practice questions that have been made: 


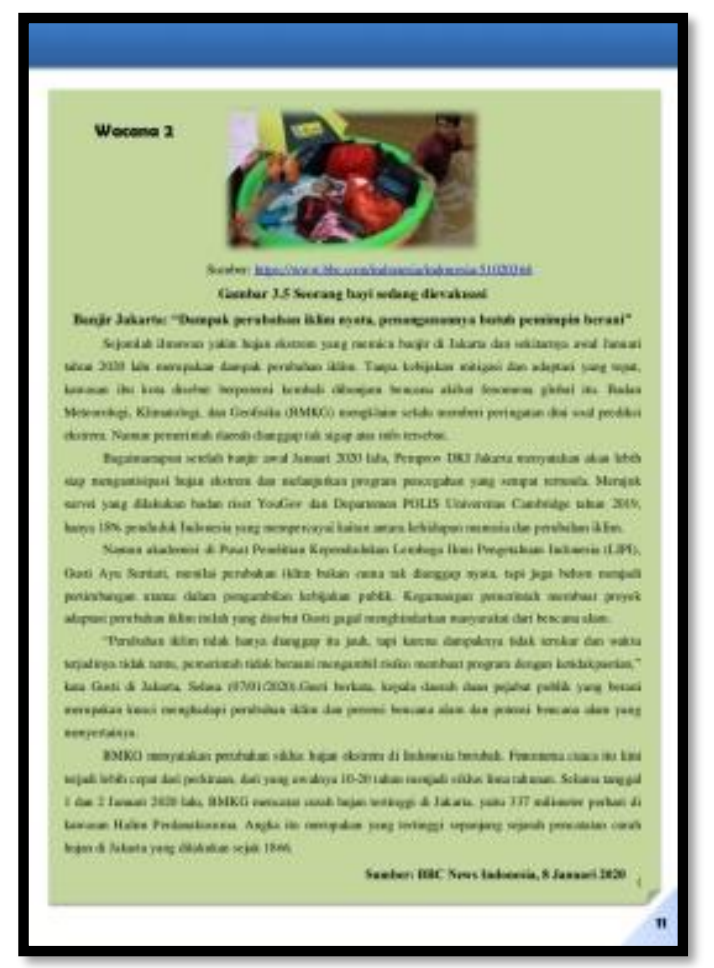

Figure 1. Display of issues presented in socio-scientific issues-based student worksheets

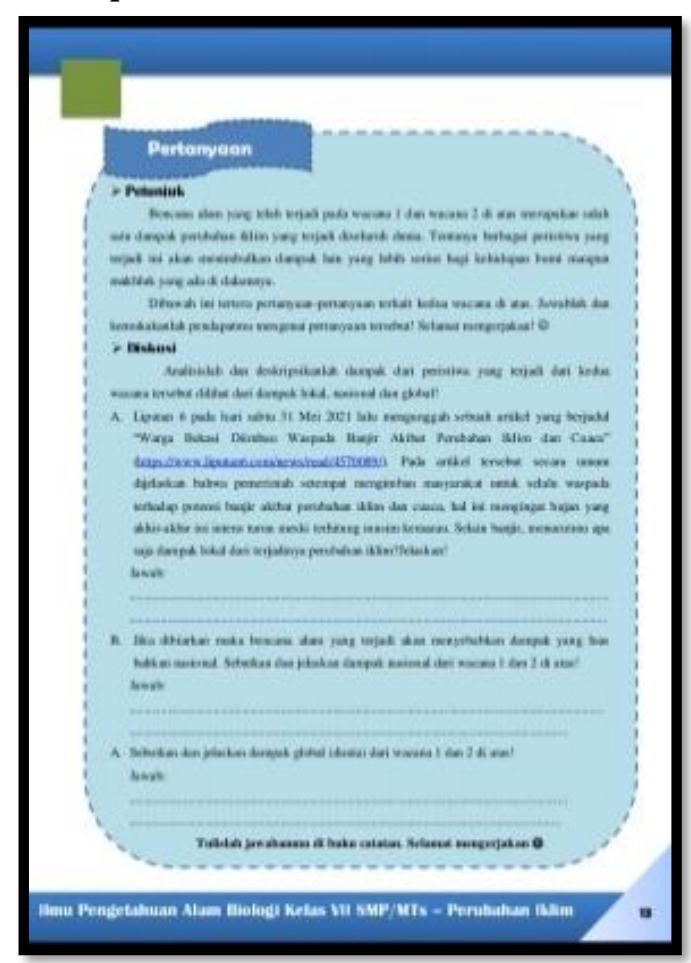

Figure 2. Display of practice questions on socio-scientific issues-based student worksheets The benefits that can be taken from the development of Socio-Scientific Issues (SSI)-based Student Work are students can be more concerned an critical in dealing with all problems related to the environment and social problems. Especially in the situation of the Covid-19 pandemic. Covid--19 is sweeping across the world and changing everyone's life in an unprecedented way 
(Ke et al., 2021). It is undeniable that bad weather and air greatly affect people's health. Every year, climate change becomes a global problem, we must face it together. The consequences of climate change are very threatening to human life around the world. The impact of climate change, one of which is the occurrence of deforestation, will make humans lack of oxygen because forests, which are the lungs of the world, are already under threat due to climate change.

From the research that has been carried out, it is known that the students' readability response to the Socio-Scientific Issues-based Student Worksheets that have been made is stated to be very valid and very feasible, the responses given by students are also very good and useful for students' daily lives and make it easier when studying material changes. climate. The research mentioned in Owens et al (2021) research supports teaching SSI as a practical means by which teachers can contextualize science content and practice in a way that students can relate to while developing scientific literacy. Teachers have several obstacles in teaching activities such as limited literature, students' difficulties in remembering scientific names, and learning materials that cannot be understood due to teacher limitations in providing real-life examples (Thurrodliyah et al., 2020).

After learning by using Student Worksheets based on Socio-Scientific Issues, students become more daring to argue about environmental problems that occur, are more sensitive to environmental problems and try to get involved directly in solving existing problems. This is in line with what was conveyed by Putriana (2020) some of the advantages of SSI learning are as follows: (1) Instilling an understanding of science to students which is expected to be applied in social life, (2) The realization of social sensitivity so that students are able to realize the results of their thoughts, (3) Improve skills in arguing in ways of opinion and logic regarding events in everyday life, (4) Developing skills in reviewing, concluding things, clarifying, evaluating, interpreting things, and being able to exercise control over themselves.

Characteristics of learning using Student Worksheets based on Socio-Scientific Issues (SSI) is that in the learning process it always prioritizes stimulating students' argumentation skills, presenting issues that are hotly discussed in the community related to environmental problems, especially on climate change material. The scope of the issues discussed is local, national to global. The differences between conventional Student Worksheets and Socio-Scientific Issuesbased Student Worksheets can be seen in the following table:

Table 3. Differences between conventional student worksheets and socio-scientific issues

\begin{tabular}{|c|c|c|}
\hline No & Conventional student worksheets & Socio-scientific issues based student worksheets \\
\hline 1 & $\begin{array}{l}\text { Learning is carried out only to direct } \\
\text { the activities of students to understand } \\
\text { or direct the concepts that have been } \\
\text { studied by students before. }\end{array}$ & $\begin{array}{l}\text { Learning directs the activities of students to analyze the } \\
\text { problems that are happening and trains students to } \\
\text { solve these problems in terms ofaspects Local, National } \\
\text { and Global. }\end{array}$ \\
\hline 2 & $\begin{array}{l}\text { Students only focus on the activities } \\
\text { shown in the LKS. }\end{array}$ & $\begin{array}{l}\text { Students try to analyze and think critically about the } \\
\text { problems presented with the aim of training students' } \\
\text { attitudes in making every decision and being able to } \\
\text { find concepts independently. }\end{array}$ \\
\hline 3 & $\begin{array}{l}\text { Less highlighting social, moral, and } \\
\text { ethical attitudes. }\end{array}$ & $\begin{array}{l}\text { In practice questions and presenting the existing } \\
\text { issues/news aims to train students' social, moral, and } \\
\text { ethical attitudes to become more concerned with the } \\
\text { problems of climate change that occur. }\end{array}$ \\
\hline 4 & $\begin{array}{l}\text { The questions and exercises given are } \\
\text { only to increase knowledge and are } \\
\text { rote and theoretical in nature. }\end{array}$ & $\begin{array}{l}\text { The questions and exercises given are in the form of } \\
\text { presenting material in the form of issues/news problems } \\
\text { with the aim of training students' skills in solving a } \\
\text { problem that occurs }\end{array}$ \\
\hline
\end{tabular}




\section{Conclusion}

Based on the research that has been done, it is concluded that the worksheet based on SocioScientific Issues (SSI) on climate change material is very valid and very suitable to be used as a medium of learning in SMP class VII with the acquisition of a student readability response value of $90 \%$. The characteristics of the Socio-Scientific Issues-based Student Worksheets that have been developed include expressing opinions and determining various individual and community choices. The issues included are often broadcast and broadcast in multiple media. The issues discussed in the Student Worksheets are related to local, national, and international coverage and global, socially, and morally bound. This Socio-Scientific Issues-based Student Worksheet is declared valid because based on the readability results obtained by students, it is generally stated that the Student Worksheet made is capable of being a solution to achieve 21st-century competencies that can connect science and life so that it can be used as an alternative learning science resource in the classroom. In the research that has been developed, there are still shortcomings, such as not including terms that are quite difficult in the introduction. The author recommends further research; hopefully, it can be better. If necessary, it can also be used to determine the scientific literacy skills of students in learning science, especially biology.

\section{References}

Aisya, N., Wibowo, Y., \& Aminatun, T. (2017). The influence of socio-scientific issues on reflective judgment of high school's student in ecosystem material. Jurnal Bioedukatika, 4(2), 14. https://doi.org/10.26555/bioedukatika.v4i2.5346

Ameliawati, M. (2021). Pengembangan lembar kerja siswa berbasis socio-scientific issues (ssi) pada materi perubahan iklim. Skripsi. Universitas Islam Negeri Sunan Gunung Djati Bandung.

Anagün, Ş. S., \& Özden, M. (2010). Teacher candidate's perceptions regarding socio-scientific issues and their competencies in using socio-scientific issues in science and technology instruction. Procedia - Social and Behavioral Sciences, 9, 981-985. https://doi.org/10.1016/j.sbspro.2010.12.271

Anggraini, R., Wahyuni, S., \& Lesmono, A. D. (2016). Pengembangan lembar kerja siswa (lks) berbasis keterampilan proses di SMAN 4 Jember 1). Jurnal Pembelajaran Fisika, 4(4), 350-365.

Astuti, Y., \& Setiawan, B. (2013). Pengembangan lembar kerja siswa (LKS) berbasis pendekatan inkuiri terbimbing dalam pembelajaran kooperatif pada materi kalor. Jurnal Pendidikan IPA Indonesia, 2(1), 88-92. https://doi.org/10.15294/jpii.v2i1.2515

Campbell-Lendrum, D. H., Woodruff, R., Prüss-Üstün, A., Corvalán, C. F., \& Organization, W. H. (2007). Climate change: quantifying the health impact at national and local levels. 14. https://apps.who.int/iris/handle/10665/43708\%0Ahttps://apps.who.int/iris/bitstream/106 65/43708/1/9789241595674_eng.pdf

Chomsin, W. (2008). Panduan Menyusun Bahan Ajar Berbasis Kompetensi. PT Elex Media Komputindo.

Espeja, A. G., \& Lagarón, D. C. (2015). Socio-scientific Issues (SSI) in initial training of primary school teachers: pre-service teachers' conceptualization of ssi and appreciation of the value of teaching SSI. Procedia - Social and Behavioral Sciences, 196(July 2014), 80-88. https://doi.org/10.1016/j.sbspro.2015.07.015

Fibonacci, A. (2020). Literasi Sains dan implementasinya dalam pembelajaran. Insan Cendekia Mandiri.

Fikria, U. R. A., \& Prodjosantoso, A. K. (2021). Teaching tools based on socio-scientific issues on acid-base topic for chemistry learning at high school: A needs analysis. Proceedings of the 6th International Seminar on Science Education (ISSE 2020), 541(Isse 2020), 289-295. https://doi.org/10.2991/assehr.k.210326.041

Foong, C. C., \& Daniel, E. G. S. (2010). Assessing student's arguments made in socio-scientific contexts: The considerations of structural complexity and the depth of content knowledge. 
Procedia - Social and Behavioral Sciences, 9, 1120-1127. https://doi.org/10.1016/j.sbspro.2010.12.294

Friedrichsen, P. J., Sadler, T. D., Graham, K., \& Brown, P. (2016). Design of a socio-scientific issue curriculum unit: antibiotic resistance, natural selection, and modeling. International Journal of Designs for Learning, 7(1), 1-18. https://doi.org/10.14434/ijdl.v7i1.19325

Hariapsari, K. W., Tukiran, T., \& Sudibyo, E. (2018). Validity of teaching materials based on socio-scientific issues approach on the topic of vibration, waves, and sound. Journal of Physics: Conference Series, 1108(1). https://doi.org/10.1088/1742-6596/1108/1/012034

Ke, L., Sadler, T. D., Zangori, L., \& Friedrichsen, P. J. (2021). Developing and using multiple models to promote scientific literacy in the context of socio-scientific issues. Science and Education, 30(3), 589-607. https://doi.org/10.1007/s11191-021-00206-1

Komara, E. (2018). Penguatan pendidikan karakter dan pembelajaran abad 21. SIPATAHOENAN: South-East Asian Journal for Youth, Sports \& Health Education, 4(1), 17-26.

Lawhon, D. (1976). Instructional development for training teachers of exceptional children: A sourcebook. Journal of School Psychology, 14(1), 75. https://doi.org/10.1016/00224405(76) $90066-2$

Lee, Y. C. (2007). Developing decision-making skills for socio-scientific issues. Journal of Biological Education, 41(4), 170-177. https://doi.org/10.1080/00219266.2007.9656093

Maryamah, I., Anriani, N., \& Fathurrohman, M. (2019). Pengembangan bahan ajar materi pythagoras yang berorientasi pada kompetensi abad 21 untuk guru SMP. SJME (Supremum Journal of Mathematics Education), 3(1), 67-77. https://doi.org/10.35706/sjme.v3i1.1490

Muslimah, S., Rosalina, E., \& Febriandi, R. . (2021). Pengembangan lembar kerja siswa (lks) tematik berbasis outdoor learning pada siswa sekolah dasar. JURNAL BASICEDU, 5(4), 19261939. https://doi.org/https://doi.org/10.31004/basicedu.v5i4.1069

Nazilah, N., Muharrami, L. K., Rosidi, I., \& Wulandari, A. Y. R. (2019). Pengaruh Bahan ajar berbasis socio-scientific issue pada materi pemanasan global terhadap kemampuan literasi sains siswa. Natural Science Education Reseach, 2(1), 8-16.

Owens, D. C., Sadler, T. D., \& Friedrichsen, P. (2021). Teaching Practices for enactment of socio-scientific issues instruction: an instrumental case study of an experienced biology teacher. Research in Science Education, 51(2), 375-398. https://doi.org/10.1007/s11165-0189799-3

Pane, A., \& Darwis Dasopang, M. (2017). Belajar dan pembelajaran. FITRAH:Jurnal Kajian IlmuIlmu Keislaman, 3(2), 333. https://doi.org/10.24952/fitrah.v3i2.945

Putriana, A. R. (2020). Pengembangan 1kpd Berbasis Socio Scientific Issue (Ssi) Pada Pembelajaran IPA SMP Kelas VII. Jurnal Pajar (Pendidikan Dan Pengajaran), 4(1), 80-89. https://doi.org/10.33578/pjr.v4i1.7919

Rachmawati, R. C., \& Diningsih, E. (2021). Pengenalan Sosio Scientific Issue secara Daring terhadap Kemampuan Penalaran Siswa. Media Penelitian Pendidikan: Jurnal Penelitian Dalam Bidang Pendidikan Dan Pengajaran, 15(1), 31-36. https://doi.org/10.26877/mpp.v15i1.7840

Rahayu, S., Meyliana, M., Arlingga, A., Reny, R., Siahaan, P., \& Hernani, H. (2017). Development of Lesson Plans and Student Worksheets Based Socio-Scientific Issues on Pollution Environmental Topic. Journal of Physics: Conference Series, 895(1). https://doi.org/10.1088/1742-6596/895/1/012150

Sadler, T. D. (2004). Informal reasoning regarding socioscientific issues: A critical review of research. Journal of Research in Science Teaching, 41(5), 513-536. https://doi.org/10.1002/tea.20009

Sadler, T. D. (2009). Situated learning in science education: Socio-scientific issues as contexts for practice. In Studies in Science Education (Vol. 45, Issue 1). https://doi.org/10.1080/03057260802681839

Sadler, T. D., Romine, W. L., \& Topçu, M. S. (2016). Learning science content through socioscientific issues-based instruction: a multi-level assessment study. International Journal of Science Education, 38(10), 1622-1635. https://doi.org/10.1080/09500693.2016.1204481 
Sriwiyana, A. \&. (2011). Instrumen perangkat pembelajaran. Rosda Karya.

Sujana, I. W. C. (2019). Fungsi dan tujuan pendidikan Indonesia. Adi Widya: Jurnal Pendidikan Dasar, 4(1), 29. https://doi.org/10.25078/aw.v4i1.927

Thurrodliyah, N. I., Prihatin, J., \& Novenda, I. L. (2020). the development of brain-based learning model based on socio-scientific issues ( Bbl-Ssi ) for Biology Learning in Senior High School. ScienceEdu, 3(2), 32-42.

Yaumi, Madlazim, \& Taufikurohmah, T. (2019). Development of science learning material with socio-scientific issues (ssi) on climate change materials to improve science literacy of junior high school studentS. Jurnal Penelitian Pendidikan IPA, 4(2), 56-63. 